\title{
Dorothy Heathcote İçin Ertelenmiş Bir Yazı...
}

\section{Ömer Adıgüzel ${ }^{1}$}

Dergi editörümüz Fatma Önalan Akfırat ${ }^{2}$, Dorothy için yapacağımız özel sayı için benden bir giriş yazısı istemişti. Ben de kabul etmiş en iyi yazma anının gelmesini beklemeye başlamış gibiydim. Bir gün bir ilham gelecek ve ben en iyi Dorothy yazısını yazmış olacaktım. Bu nedenle onunla ilgili yeni kaynaklara ulaşmalı, onları okumalı ve iyi bir analizden sonra da Dorothy'nin drama anlayışını da içeren yazıyı yazmalıydım.

Başlangıçlar yapıyor, ilk tümceleri yazıyor ancak sonrasını getirmek için onun hakkında yazılmış tez ve kitaplara özellikle de Gavin Bolton'un ${ }^{3}$ gerçekleştirdiği yaşam öyküsüne odaklanıyordum. Kitabın bir yerinde Dorothy'nin çocukluk zamanlarında bir öğretmeninden çok fazla etkilendiğini, hayranlık duyduğu bu öğretmeninin kısa bir süre sonra ciddi bir hastalığa yakalandığını, Dorothy'nin ise öğretmenini ziyaret etmek için yaklaşık 25 kilometre uzaklıktaki hastaneye bisiklet ile gittiğini anlatıyordu. Hastanede ise öğretmeninin hastalıkla başa çıkma konusundaki azminden, o hastanedeki hapishane yaşamına rağmen gülümsemesinden çok derinden etkilendiği üzerinde duruyordu. Dorothy'nin daima bir yaşam mücadelesi içerisinde bile sürekli gülümsemesinin kaynağı anlaşllıyordu. Sonra onu hep uzaklara götüren hayal dünyası ve onu oralarda tutan sorumluluk duygusu gibi iki uç dünyaya sahip olduğunu ve Dorothy'nin bu iki dünyaya da tüm enerjisini vererek, ikisi arasındaki ayrımın bilincinde olarak yaşama baktığını söylüyordu.

Dorothy Heathcote'u bu dört sözcük ya da sözcük öbeği rahatlıkla anlatıyordu. Karşımda inanılmaz bir yaşam vardı ve giriş yazımın da kısa sürede biteceği yoktu. Sonra beklenen bu yazı bir türlü bitemediği için dergimizi yayınlayamamış, kendisine de yaşamdayken ulaştırma mutluluğunu yaşayamamıştık. Ben yazıyla uğraşırken ve bu arada yaratıcı drama alanına ilişkin yazdığım kitaba Dorothy'nin yazdığı önsözü okurken ölüm haberi gelmişti. Yazının bitmemesi ve ötelenmesi için nedenler artıyor gibiydi. Tümceler yazılamıyor, sözcükler anlamlı sıralar izleyerek dizilmeye direniyorlardı sanki. Onun yaşama veda edişinin ardından yazdığım yazıya ilişkin aldığım dönütler, bu yazının sanıyorum benim yüzümden ertelenmiş ve ötelenmiş bu özel sayıya da uygun olacağını gösteriyordu. Bu nedenle tüm yaratıcı drama dünyası ile bu ötelenmiş yazıyı yeniden paylaşıyorum:

\section{"Sevgili Dorothy,}

Sana buradan, bu köşeden hem de ardından yazı yazacağımı hiç düşünmez ihtimal bile vermezdim. Mesajı aldığımda çakılıp kaldım. Evde salondaydım. Salonda elini öperken çekilmiş fotoğrafımız var... Seni tanımayanların sorduğu "Kim?" sorusuna "Eli Öpülecek Kadın!" diye yanıtladığım fotoğrafına yeniden baktım. Sonra arşivden diğer fotoğraflarını sıraladım. Dikkatimi çeken ilk ve tek şey hepsinde yüzünde hiç eksilmeyen bir gülümsemenin olması ve tüm enerjinin her karede görülmesi... İşte bu yüzden bu kötü habere, ne kendim ne de

1 Doç.Dr.Ankara Üniversitesi Eğitim Bilimleri Fakültesi Öğretim Üyesi, Çağdaş Drama Derneği Genel Başkanı.

2 Dr. Fatma Önalan Akfırat, Milli Eğitim Bakanlığı'nda Psikolojik Danışman, Yaratıcı Drama Eğitmeni.

3 Bolton, G. (2003). Dorothy Heathcote's Story. UK and Sterling, USA. 
seni tanıyan tüm arkadaşlarım kendimizi hiç alıştırmamıştık. Yakıştıramazdık doğrusu... Son mektuplarını nasıl da saklıyorduk...

Yaratıcı drama eğitimine başladığım ilk yıllarda Sevgili öğretmenlerim İnci $\operatorname{San}^{4}$ ve Tamer Levent ${ }^{5}$, senin yaptığın birkaç atölyeden görüntüleri bizlerle paylaşmış ve yorumlarda bulunmuştuk. Cezaevi konulu çalışmanı yaparken çocuklarla ilk karşılaşmandan ve onlara rol içindeki verdiğin yönergenden çok etkilenmiş̧im. Tüm çocuklar o anda sana odaklanmıştı ve gözlerini ayırmıyordu. Seni izleyenler de çalışmanın içinde olanlar da ikinci bir hareketini, yeni bir söz yazmanı bekliyorlardı.. Ben de yıllar sonra bu görüntüleri izlerken sana ve yarattığın o enerjiye kilitlenip kalmıştım.

Seni Türkiye'den sanıyorum ilk tanıyan, yaşadığı yere giden, onunla ilk söyleşiyi yapıp yayımlayan Tamer Levent'in yazdıklarını, söylediklerini nerdeyse ezberlemiştim. Pek çok yazı ve çalışmamda konu etmiştim seni. Ne okursam okuyum karşıma hep sen çıkıyordun ve katılımcı liderlik konusunda yaptıklarımla hep örtüşüyor gibiydik. İnci Hoca bir drama sohbeti sırasında "Bizde Ömer hep katılımcıların arasına katılır ve onlarla birlikte çalışır" dediğinde ben seni daha hiç tanımıyordum. İşte o ilk görüntülerini izlediğimde kilitlenmemin nedeni anlıyorsun değil mi?

Yıllar sonra Atina'ya kongreye gidecektim. İsmail Güven ${ }^{6}$, listeden ismini gösterdiğinde inanamamıştım. Atina yazmış, gerçekten oraya gelip gelmeyeceğini sormuştum. Sonra Drama dünyasından meslektaşım Nicos Govas' $\tan ^{7}$ bana mutlaka bir randevu almasını talep etmiştim... Nicos, zor diye yazmıştı...

Kongre resmi olarak Atina Üniversitesi'nde açılmış, akşam da kokteyle gidiyorduk. John O’Toole ${ }^{8}$ ile "Süreçsel” sözcüğününilkininkime aitolduğunu konuşuyorduk. Bu konuşmalarımda İsmail hep yanımda ve benim adıma aktarıyordu. Birden İsmail salonun köşesinde yalnız oturan birini gösterdi ve "Bak işte orda oturuyor!" demişti. İkinci kilitlenmeyi yaşıyordum... Hemen yanına gittik. Patates haşlamaların olduğu bir saklama kabını açmış, atıştırmaya başlamışıın. "Merhaba!" demiştik, o bildik güler yüzün ile "Merhaba!" demiştin..."Yaratıcı dramanın Tanrıçası Dorothy Heathcote ile mi tanışıyorum?" diye sormuştum "Abartma lütfen!" diye yanıt vermiş̧in. "Sağlık nedenleri ile diyetim olduğu için başka şeyler yiyemiyorum" demiştin... Hiç olmadık bir konuyu konuşuyorduk ve şaka değil bir kokteyl ortamında karşımdaydın. Sen, İsmail ve ben bir köşedeydik ve kimse sanıyorum fark etmemişti senin orda olduğunu... Kongre süresince bir saatini bana ayırıp ayırmayacağını sormuştum. Kızıma sorun, benim zamanlamamı o yapıyor demiştin. Ertesi gün açılış konferansını dinlemiştik. Müthiş enerjik, etkileyiciydi. Ne yazık ki araya giren ikinci dil nedeniyle çoğunu anlayamamıştım.

Çok sonraları metin elime ulaştığında da üçüncü kilitlenmeyi yaşamıştım... Ömrüm boyunca beni bulunduğum yerde dondurup bırakacağının habercisi gibiydi seninle yaşayacaklarımız. Bunu çok yakından hissediyordum... Ne kadar abartmış olursam olayım, gizli bağ ile kongre boyunca sürekli olarak seni izliyor ve sürekli yanı başında olmaya çalışıyordum.

4 Prof. Dr. İnci San, Çağdaş Drama Derneği kurucularından ve Onursal Başkanı.

5 Tamer Levent, Devlet Tiyatroları Sanatçısı, TOBAV Başkanı, Çağdaş Drama Derneği kurucularından.

6 Prof. Dr. İsmail Güven, Ankara Üniversitesi Eğitim Bilimleri Fakültesi Öğretim Üyesi.

7 Nicos Govas, Yunanistan Drama, Tiyatro ve Eğitim Ağı.

8 Prof. Dr. John O’Toole Avustralya'da Drama Eğitimcisi. 
İDEA'nın ilk toplantısına katıldığımızda toplantıya biraz geç gelmiş, İsmail Güven, Ali Öztürk ${ }^{9}$ ve benim oturduğum masaya oturmuştun, izin isteyerek. "Bu bir mucize!" diyordum kendi kendime... Toplantı bittikten sonra Ali video kameraları açmış ayaküstü bir söyleşi yapmıştık seninle... Söylediklerimi çok iyi hatırlıyorum. "Dorothy, Yunanistan'da pek çok tanrı ve tanrıça var. Ama ne şanslılar ki Yaratıcı Dramanın da tanrıçasını buraya getirdiler. Ama biliyor musun Türkiye'de seni tanımak isteyen bir kez görmek isteyen çok kişi var. Ankara'ya gelir misin? Bu tanrıça Ankara'ya gelir mi?" demiştim. "Lütfen abartma. Çok yaşlandım ve ailem yolculuk yapmama izin vermiyor artık" demiştin... "Ama..." diyor sözün sonunu da getiremiyordum... Kongre süresince her firsatta bu davetimi yenilemiştim. "Kızıma sor, onu ikna edersen, olur demiştin." İsmail Güven eksik olmasın, benim bu tutkumu çok iyi anladığından Dorothy'in kızı Marianne ile durmadan konuşmuş ve Kongre'nin bitimine bir gün kala "Evet, geliyoruz!" demeyi başartmıştı. İnanamıyordum. Gerçek olup olmadığını soruyordum habire... Telefonumun şarzı bitmek üzereydi, sanıyorum önce İnci Hoca'ya sonra da Özlem Gökbulut'a ${ }^{10}$ haber verebilmiştim. Şarjım bittiği için de o an başka kimse ile paylaşamamıştım.

2008 yılı Çağdaş Drama Derneği'nin tarihi günlerinden biriydi. Dramanın tanrıçası olan sen Ankara'daydın. Türkiye'de senin adının ilk kez anıldığı Eğitim Bilimleri Fakültesi'ndeydin. Sonra seni Kongremizin yapılacağı salona almıştık. Koluma girmiştin. Salonun ön koltuğuna beraber gitmiştik. Ayaklarım titriyordu. Dolu salon seni ayakta alkışlıyordu... Açılış konuşmanı yapmıştın yine o bitmez tükenmez halinle... Sonra Derneğimizin Fahri Üyeliğini ve "Yaşam Boyu Başarı Ödülü” nü İnci Hoca sana sunmuştu... Aynı karedeydik... Göz kırpmıştın bir an bana... Yeni bir kilitlenmeydi yaşadığım. İnanılmaz mutluydum. Dernekteki tüm arkadaşlarım, meslektaşlarım, öğrencilerim seferber olmuşlardı. Aynı onuru yaşıyorduk. Sen Ankara'da Çağdaş Drama Derneği'nin konuğuydun ve üç gün boyunca hiç oturmadan saatlerce ayakta yaptığın atölye (birkaç kişi senin el ele tutup çember yapıp oyun oynatmanı bekliyordu yine ama...) hepimize ayrı bir ayna tutmuştu. Utanmıştık galiba. Bu istek, bu işini zevkle yapma durumu, sanki yeni başlamış gibi...

Sonra seninle uzun bir söyleşi yapmıştık. Yakında dergimizde yayımlanacaktı. Giriş yazısı için Dergi editörümüz beni sıkıştırıp duruyordu... Hep bir şeyler eksik kaldı diyerek onu atlatıyordum. Meğer vefat haberini de bu yazıya yazmam gerekecekmiş... Çok iyi yaşantı ve anılarla ayrıldığını söylemiştin Ankara'dan ayrılırken... Çok zor geldiğini biliyordum. Seni çok iyi anlıyorduk, ama beni kırmamıştın... İçimde bir kez daha davet edersem yine kırmayacağın düşüncesi oluşmuş, bu kez çocuklarla çalışmak üzere seni davet etmiştim. Çalışma İngilizce bilen çocuklarla yapılacak, bizler de izleyecektik... Yüzün üzerinde kişi seni izleyecektik. Kabul etmiştin. Havalarda uçuyordum sanki. Yazışmaları Oylum ${ }^{11}$ yapıyordu ve ona diyordum ki bu mektuplar için ne kadar şanslısın... Ona Türkçe ve çevrilmiş haliyle İngilizce mektuplar yaziyordum, her birine kendi el yazısı ile hemen yanit veriyordu. Her bir soruya hem de ayrıntılarıyla... Yazacağım kitaba önsöz istemiş̧im senden. Önce içindekiler bölümünü isteyip, sonra da kendi el yazın ile metni bana posta ile ulaştırmışıı...

9 Yard. Doç. Dr. Ali Öztürk, Anadolu Üniversitesi, Eğitim Bilimleri Enstitüsü Eğitimde Drama Anabilim Dalı Başkanı, Çağdaş Drama Derneği Eskişehir Şubesi Başkanı

10 Özlem Gökbulut, Çağdaş Drama Derneği Genel Başkan Yardımcısı

11 Doç. Dr. Oylum Akkuş İspir, Hacettepe Üniversitesi Öğretim Üyesi 
"Sevgili Ömer,

İlk kez hiçbir zaman yazıldığı dil nedeniyle okuyamayacağım bir kitaba önsöz yazıyorum..." diye başlayan bir metindi... Sonra devam ediyordu: “...Benden kitabına önsöz yazmanı istediğinde neden hiç tereddüt etmeden 'evet' dediğimi açıklayayım. Ankara'da içeriği dolu iki farklı çalışma yürüttüm. Senin ve Dernekteki arkadaşlarının nasıl konsantrasyonunuzu kaybetmeden tüm çalışma süresince çalışmalara katıldığınızı gözlemledim. Bizim mesleğimizde başkalarından bir şeyler öğrenmek az rastlanan bir durumdur, genellikle kendi düşüncelerimizin başkaları tarafından onaylanmasını bekleriz. Ama sen, Ömer bu kişisel ilgi ile gözleri kapanmamış birisin. Sen diğerlerinin çalışmasından bir şeyler öğrenmeye açıksın..." diye devam eden... Bu sevinç ve onur bana yeterdi... Kitabı hemen sana gönderme telaşındaydım... Gönderemedim. Nasıl üzgünüm şu an... Eskişehir'den Asuman'dan ${ }^{12}$ aldığım mesajında ilk söz "yetişemedim" oldu... Salondaki fotoğrafa yeniden baktım. Türk usulü el öpmeyi gösteriyordum sana. Arkadaşlar o anı fotoğraflamışlar. Çerçeveletip bana da hediye etmişlerdi... Eli Öpülecek Kadındın... Zeki Özen' ${ }^{13}$ sonra yönlendirmiş ve yüksek lisans tezini senin üzerine çalışmasını önermiştim. Zeki, sanıyorum Türkiye'de en şanslı ve ayrıcalıklı bir eğitmen/lider olacaktı. Senin evinde kalmış, söyleşiler yapmış ve tezini oluşturmuştu. Ne yazık ki onu da sana göndermeye zaman yetmedi. Ama yakında kitap olarak yayımlayacağız. Hiç olmazsa bunu duyurayım sana...

Sonraları duyduk ki İngiltere Kraliyeti sana "Yaşam Boyu Başarı" Ödülü vermiş. Bizden sonra demiş ve ayrı bir gurur duymuştuk... İşte böyle Sevgili Dorothy.

Biliyor musun yıllar önce bir 24 Ocak öğle saatlerinde yüksek lisans tezimi yazdığım bir anda Radyo haberinden Uğur Mumcu'nun ${ }^{14}$ öldürüldüğünü duymuş, yerimde donup kalmış ve onu toprağa verene dek ağlamıştım. Ben bu sabah sana çok ağladım Dorothy. Hem seni tanımış, senin elini öpmüş, seni Ankara'da da görmüş, pek çok kişinin seni görmeni sağlamış biri olmanın sevinci ile Derneğimizin bu onuru yaşamış olması nedeniyle ve bir o kadar da sözlerin bittiği ve söylenecek hiçbir sözün kalmadığı bir üzüntü ile ağladım.

Parmaklarım zorlandı ilk mesajları yazarken. İnci Hocayı Tamer Hocayı aradım. Diğer birkaç meslektaşımı aradım. Bir an ne yapacağımı bilemedim. Masamın üstüne yazılmış kitaplarına bir kez daha baktım. O güleç yüzlü fotoğrafın gözlerimin önünde. Biraz önce tıpkı diğerleri gibi Songül Başbuğ ${ }^{15}$ aradı beni "Sizin duygusal yakınlığınızı bildiğimden size baş sağlığı diliyorum" dedi... Ben yine ağladım. Hem de Uğur Mumcu'dan sonra yeniden...

Sana ne yazayım ne diyeyim bilmiyorum. Ama ben seni hep çok sevdim. Meslek yaşamım boyunca senin etkilerini çok hissettim. Yaşamın en güzel dillerinden biri olan dokunma dili ile bana ve bizlere dokunduğunu çok iyi biliyorum, öyle ki parmak izlerin her yerde...

Sevgiyle ve dostlukla ...9 Ekim 2011"

Son olarak şunu söyleyebilirim ki, Dorothy Heathcote'u bilmeden yaratıcı drama eğitmeni olunamaz!

12 Asuman Vural, Çağdaş Drama Derneği Eskişehir Şubesi Yönetim Kurulu Üyesi

13 Zeki Özen, Ankara Üniversitesi Eğitim Bilimleri Enstitüsü Doktora Öğrencisi, Araştırma Görevlisi

14 Uğur Mumcu, Cumhuriyet Gazetesi yazarı olarak çalışırken 24 Ocak 1993’te Ankara'da Karlı Sokak’taki evinin önünde, arabasına konulan bombanın patlaması sonucu suikasta kurban giderek yaşamını yitirmiştir.

15 Songül Başbuğ, Çağdaş Drama Derneği Yönetim Kurulu Üyesi 


\section{A Delayed Prolog for Dorothy Heathcote...}

\section{Ömer Adıgüzel ${ }^{1}$}

Our journal editor, Fatma Önalan Akfirat ${ }^{2}$, requested me to write a prolog for the special issue to be published about Dorothy. I accepted and started to wait for the best moment to come for writing. One day, I would find the inspiration I needed and would be able to write the best for Drothy. To do so, I thought that I had to have access to new resources about her, read them and after a good analysis, write the text including her understanding of drama. I was writing some introductions, writing the first few sentences and then focusing on the theses and books written about her, particularly on her biography penned by Gavin Bolton ${ }^{3}$. In some part of the book, it is said that Dorothy was deeply affected by one of her teachers, she greatly admired her but after a while, the teacher got seriously ill and Dorothy went to a hospital which was 25 kilometers away on a bicycle to visit her. It is emphasized in the book that Dorothy was greatly affected by her teacher's willpower to cope with the illness and her continuous smiling in spite of hard conditions she were in at the hospital. From this, it has become clear how Dorothy was able to smile even when she was in difficult situations. Then the book goes on saying that she had two extreme words, one of which is the world of imagination taking her faraway lands and the other is the world of responsibility which keeps her where she goes and she views the life by giving all her energy to these two worlds and being aware of the separation of the two.

These four words or phrases clearly explain what Dorothy Heathcote is. I had an incredible life to write about and it was clear that it would not be easy task to do. As this expected text could not be completed, the journal could not publish the special issue on her; hence, we were not able to send the special issue to her when she was alive. While I was occupied with the writing of the prolog and reading the preface written by Dorothy for my book of creative drama, I was notified about her death. Now, it seemed that I had more reasons not to finish and put off my writing. Sentences could not be produced, and words seemed to show resistance to be ordered in meaningful ways. After her farewell to life, the feedback I got for the text I had written about her indicated that this text would be highly suitable for this special issue which was delayed mostly because of me. Therefore, I want to share this delayed text with the world of creative drama:

\section{"Dear Dorothy,}

I never thought that I would write something about you here, particularly when you are not alive. When I got the news of your death, I got shocked. I was in the living room in my house. There is a photograph of you while I was kissing your hand in the living room. When people who do not know you ask "Who is she", I answer "She is the person whose hands are worth kissing”, I looked at that photo again. Then I looked at your other photos in my photo archive.

1 Assoc. Prof. Ankara University, Instructor at the Faculty of Educational Sciences, President of Modern Drama Association.

2 Dr. Fatma Önalan Akfırat, Psychological Counselor in the Ministry of National Education, Creative Drama Instructor

3 Bolton, G. (2003). Dorothy Heathcote's Story. UK and Sterling, USA. 
The first and most important thing drawing my attention was the smile on your face which had been always there and the energy erupting from every part of the photo. Hence, we have never been able to accept this bad news.

During the first years of my creative drama education, my beloved teachers, İnci $\mathrm{San}^{4}$ and Tamer Levent ${ }^{5}$ shared some scenes from your workshops with us and we made some comments on them. When I watched your workshop with the topic of prison, I was deeply affected by your meeting with the students and instructions you gave them. All the students were focused on you and they did not even blank while watching you. Both those watching you and the ones involved in the workshop were waiting for you to write a new word. While I was watching this many years later, I was still fascinated by you and the energy you created.

I nearly memorized everything written about you by Tamer Levent, who is the first person to know you, to visit you in your place of residence and have an interview with you in Turkey. In many of my works, there are something told about you. Whatever I read, I found you there. What I did on participatory leadership seemed to always comply with your perceptions. During a conversation with İnci San about drama said "Ömer always interacts with the participants and works with them", I had not heard of you. Did you now understand why i so focused on your videos the first time i saw them? .

Years later, I was going to participate in a conference in Athens. When İsmail Güven ${ }^{6}$ showed me your name in the list, I could not believe in my eyes. Then, I requested my colleague, Nicos Govas, ${ }^{7}$ to get an appointment with you. ... Nicos replied "It is a hard task".

The conference was officially inaugurated in the University of Athens, and there was a reception in the evening of the first day. I was talking to John O'Toole ${ }^{8}$ about "the origin of the word procedural", During this conversation, İsmail was with me and was translating. Suddenly, İsmail showed me someone sitting on one corner and this person was you. We approached you while you were eating boiled potato. I said "Hello", and you answered "Hi" with a smile on your face, as usual. I said "The goddess of the world of creative drama, Dorothy Heathcote, aren't you?" You said "Don't exaggerate!" and went on "I could not eat anything else on the grounds of health". I still could not believe, but it was not a joke, I was talking to you. You, ismail and I were on the corner and I think nobody was aware that you were there. I asked you whether you spare one hour for me during the congress. And she said "ask my daughter, she is the person organizing my time". Following day, we listened to you in a presentation. You were energetic and impressive. However, as the language of presentation was English, I could not understand much of it. After a while, I was able to get the text of the presentation, and once more, I was shocked. It was an indication that we would have a close bond. Throughout the congress, I always watched you and sought for any opportunity to be with you.

In the first meeting of IDEA, you were a bit late, and you came to the table where I was sitting with İsmail Güven and Ali Öztürk ${ }^{9}$, you asked whether you could sit. I thought that it was

4 Prof. Dr. İnci San, founder of Contemporary Drama Association and Honorary President.

5 Tamer Levent, an actor in State Theatres, TOBAV President, founder of Modern Drama Association

6 Prof. Dr. İsmail Güven, Faculty member in the Faculty of Educational Sciences in Ankara University.

7 Nicos Govas, Greek Drama, Theatre, and Education net.

8 Prof. Dr. John O'Toole Drama instructor in Australia.

9 Assist. Prof. Dr. Ali Özturk, Anadolu university, educational science institute, division of drama in education, 
a miracle. After the meeting ended, we turned on the video cameras and had a short interview with you. I clearly remember what you told. "Dorothy, there are many gods and goddesses in Greece. And how lucky they are, because they are able to host the goddess of creative drama here, you know that there are many people longing to see and meet you in Turkey. Do you come to Ankara?" "I asked myself; Does this goddess come to Ankara". You replied "I am an old person and my family do not let me travel anymore" ... I said "but", yet, could not finish my sentence. Throughout the congress, I repeated my invitation to Ankara many times. You always told "Ask my daughter, if you convince her, I may come". As İsmail was aware of how much I want to see you in Ankara, he always talked to your daughter and finally convinced her to come to Ankara. I could not believe. I went on asking whether this could be true. Battery of my mobile phone was about to be off but I managed to inform İnci Hoca and then Özlem Gökbulut ${ }^{10}$ about your visit to Ankara. Nobody else, as my battery was off then.

2008 witnessed one of the historical dates of Contemporary Drama Association. The goddess of drama, you were in Ankara. You were in the faculty of educational sciences where your name was first uttered. Then we went together to the salon where the congress would be held. We went to the seat where you would sit, my legs were shaking and all the people in the salon were applauding you. You made the opening speech with your unceasing energy. Then you were awarded with Honorary Membership of our association and "Reward of Life Long Success" by İnci San. We were in the same photo. You blinked me. It was an incredible moment. I was exhilarated. All my colleagues, friends and students were happy like me. You were the guest of Contemporary Drama Association in Ankara and you carried out a workshop for three days without sitting (few people were expecting you to get us to play in a circle holding hand in hand), but such a performance, such a desire to do one's job made us ashamed of ourselves.

Then, we had a long interview with you. It was going to be published in our journal soon. Our editor was urging me to write a prolog for the issue. I was avoiding him by telling something is missing. Now, I need to include news of your death in this text. You told me "I was leaving Ankara with wonderful memories...I knew that it was difficult for you to come here but you accepted our offer and I had a feeling that you might accept once more If I invited you and I once more invited you to work with children. This time it was going to be done with the children who knew English. More than hundred people were going to watch you. You accepted our invitation. I was very happy. Correspondences was conducted by Oylum ${ }^{11}$ I said her how lucky she was to write these letters. I was writing letters in Turkish and then they were translated into Turkish and sent to her. She immediately responded each letter personally. She gave detailed responses to each question. I wanted you write a preface for the book I was writing. You first requested me send you the content of the book and then sent me the preface you wrote by mail...

\section{"Dear Ömer,}

The letter started with this sentence " This is the first time I have written a preface for a book I would never been able to read due to its language" and went on "Let me explain why I said "yes" without hesitation when you wanted me to write a preface for your book. I conducted

10 Özlem Gökbulut, Contemporary drama association general head assisstant

11 Assoc. Prof. Oylum Akkuş İspir, Hacettepe University faculty member 
two workshops in Ankara. I witnessed how deeply concentrated you and your colleagues in the association were while I was conducting these workshops together with you. In our profession, it is not very common to learn something from others, usually what we expect is our beliefs' being confirmed by others. But you, Ömer, are a person who is not blind to what is happening around. You are open to learning from others." This was a great honor for me. I was planning to send the book to you. But this is not possible any more. I am really sad. The first word was 'I could not catch ' when I received a message from you by Asuman ${ }^{12}$ from Eskisehir. I looked at your photo taken in the salon. I was teaching you how to kiss hand in Turkish style. Our friends took the photo of that moment and framed it then gave it to me as a present. .. she is a women whose hands are worth kissing... I suggested Zeki Özen to carry out his master's thesis on you. Zeki ${ }^{13}$, I think, would be a privileged and lucky instructor/leader. He stayed in your house, had interviews with you and constructed his thesis. However, time did not allow us to send its completed from to you. But we will publish it as a book soon.

Then, we learned that you were awarded with "Life Long Success" reward by the royalty in England. After us, we felt really proud. You know, years ago, on 24 January, I was writing my master's thesis, when I hear the news of death of Uğur Mumcu ${ }^{14}$ on the radio, and I was like paralyzed and cried until his funeral. This morning I cried for you a lot. But I also considered myself a lucky person because I had the chance to host you in Ankara, to kiss your hands and provide many people with the opportunity to see you.

While writing the first messages, I had a great difficulty. I called İnci San and Tamer Levent. I also called few other colleagues. I did not know what to do for a moment. I looked at your books on my desk. Your smiling photo was in front of my eyes. A few minutes ago, Songül Başbug $\breve{~}^{15}$ called me and presented me her deepest condolences. I cried again.

I do not know what to tell more, but I love you much. I felt your impact throughout my professional career. I know that you touched us with the best language of life, touching, in that your finger prints are everywhere.

With love and friendship ...9 October 2011"

As a last word, without knowing Dorothy Heathcote, one cannot be a drama instructor!

12 Asuman Vural, Board member of Eskişehir branch of Contemporary Drama Association

13 Zeki Özen, Ankara University PhD student at educational science institute, research assisstant.

14 Uğur Mumcu who was working as a writer in Cumhuriyet Newspaper, was murdered at January 24, 1993 in

front of his house in Karli Street in Ankara because of bomb explosion in his car.

15 Songul Basbug, Contemporary Drama Association general board member. 